Journal of Agricultural Sciences
(Tarim Bilimleri Dergisi)

\title{
Effect of Production System and Slaughter age on Some Meat Quality and Digestive Tract Traits of Pheasants (Phasianus colchicus)
}

\author{
Musa SARICA ${ }^{a}$ iD, Umut Sami YAMAKa ${ }^{\text {iD }}$, Mehmet Akif BOZ ${ }^{\text {b }}$, Ahmet UCAR $^{c}$ iD \\ ${ }^{a}$ Department of Animal Science, Agricultural Faculty, Ondokuz Mayis University, Samsun, TURKEY \\ ${ }^{b}$ Department of Animal Science, Agricultural Faculty, Yozgat Bozok University, Yozgat,TURKEY \\ ${ }^{c}$ Department of Animal Science, Agricultural Faculty, Ankara University, Ankara,TURKEY \\ ARTICLE INFO \\ Research Article \\ Corresponding Author: Umut Sami YAMAK, E-mail: usyamak@omu.edu.tr \\ Received: 25 July 2019 / Revised: 11 September 2019 / Accepted: 30 September 2019 / Online: 18 January 2021
}

\section{ABSTRACT}

Male and female mixed 200 pheasants were reared in intensive and outdoor conditions to assess the meat quality and some digestive tract traits. Color, $\mathrm{pH}$, cooking loss, water holding capacity and drip loss were determined as meat quality traits. Production system did not have significant effect on most of meat quality traits. Conversely, most of these traits were affected by slaughter age. Water holding capacity significantly decreased but cooking loss increased by slaughter age. Total digestive system weight rate to body weight was decreased by slaughter age but did not differ between production systems. Small and large intestine lengths were significantly longer in indoor system and significantly decreased by slaughter age.

Keywords: Pheasant, meat quality, digestive system, water holding capacity, $p H$

(C) Ankara University, Faculty of Agriculture

\section{Introduction}

Chicken and turkey meat have reached the $93.5 \%$ of total poultry meat consumption in the World (Faostat 2017). Similar rearing conditions and same feed formulas have made the tastes of both turkey and chicken meat similar to each other. This prompted consumers to seek alternative poultry tastes. Game birds are good sources for the consumers and pheasants have highest rate in total consumed game meat (Bodnar et al. 2010). But it is also hard for people to reach these products. Therefore, it is important to produce game birds in intensive or semi intensive conditions. Poultry meat consumers are mostly interested in the production conditions of birds (Adamski et al. 2017) and animal welfare becomes more important in years. On the other hand, consumers' demands have to be met in these animal friendly production systems.

Pheasants are bred in intensive conditions for releasing to hunting areas. Farming of pheasants is also done for slaughter and meat production (Golze 2010). Meat quality of captured/ hunted (Hofbauer et al. 2010) or intensively reared (Kokoszynski et al. 2012) pheasants was investigated in previous studies. On the other hand, it was reported that by raising game birds under free-range systems, they could have a taste more similar to game-bird meat (Yamak et al. 2018). Meat quality of pheasants reared in extensive system was given by Franco \& Lorenzo (2013). There is a need of detailed information on the comparison of meat quality of pheasants reared in outdoor and indoor systems. Also, the effect of production system on digestive traits of poultry species was shown before (Bartlett et al. 2015). Therefore, the effects of production system (indoor \& outdoor) on some meat quality and digestive traits of pheasants were investigated in the current study.

\section{Material and Methods}

This study was performed at the Ondokuz Mayis University Agriculture Faculty Research Farm during May-August 2015. Experimental Animals Ethical Committee of the university approved the study. Eggs were collected from a flock of pheasants obtained from the Turkish Ministry of Forests and Water Affairs' Samsun Breeding Station. All eggs were transferred to the farm's hatchery on the same day which they were collected. Eggs were incubated for 25 days. After hatching, 200 day-old chicks were randomly selected and used in the experiment. 
Chicks were randomly allocated to pens belonging to either an indoor or outdoor-access ('free range') production system that were interspersed within windowed houses, with 4 pens per system and 25 chicks per pen. The pens were in dimensions of $3.5 \times 3.5 \mathrm{~m}$. Wire mesh was used to keep birds from flying between pens. One round feeder and 1 round drinker was placed in each pen. Wood shavings used as litter in the pens. Infra-red heaters were used for heating of the house, while lighting was applied with economic white bulbs. During first three days, 24-h lighting was applied and incrementally decreased to 20 hours over Days 3-14 and then remained constant until 6 weeks, after which natural lighting (app.14 h day ${ }^{-1}$ ) was applied until slaughter. Each replicate had its own outdoor area measuring 14x3.5 m separated by an exit door. The doors of pens were opened when pheasants reached 6 weeks of age and kept opened until the end of study. The floor of outdoor area was soil and some tree branches were placed on floor area for perching of birds. Pens were divided by wire mesh walls with height of 2 meters. Also, the top of outdoor area was covered with wire mesh for preventing birds flying.

Corn and soybean meal based feed and water were provided ad libidum. Until 12 weeks of age feed with given ingredients was supplied (190 g CP and 11.72 MJ ME, $10.0 \mathrm{~g}$ lysine, $4.0 \mathrm{~g}$ methionine, $11.0 \mathrm{~g} \mathrm{Ca}, 7.0 \mathrm{~g} \mathrm{P,}, 120 \mathrm{mg} \mathrm{Mn,} 15 \mathrm{mg} \mathrm{Cu}, 100 \mathrm{mg}$ Zn per kg). After 12 weeks to slaughter feed as given were provided (160 g CP, $11.30 \mathrm{MJ} \mathrm{ME}, 3.50 \mathrm{~g}$ methionine, $7.20 \mathrm{~g}$ lysine, $10.0 \mathrm{~g} \mathrm{Ca}, 4.00 \mathrm{~g} \mathrm{P}$ per $\mathrm{kg}$ ).

All birds were wing-banded to identify individually. Live weights were recorded individually by an electronic bascule with the precision of $0.01 \mathrm{~g}$ (Hassas electronic scales, TEM TPG, İstanbul, Turkey) at hatch, 2, 4, 6, 8, 10, $12,14,16$ and 18 weeks of age. Two males and two females per pen were slaughtered at 14, 16 and 18 weeks of age. Live weights were recorded prior to slaughter. Scalding (1 min. at $\left.56{ }^{\circ} \mathrm{C}\right)$, picking, cold-water chilling, vent opening, evisceration and air-chilling were performed using semi-automated equipment. Hot-carcass weights were recorded; carcasses were then chilled for 12 hours at 4 ${ }^{\circ} \mathrm{C}$, and cold-carcass weights recorded.

$\mathrm{pH}$ values of meat were measured on left breast and legs after carcasses chilled 12 hours at $4{ }^{\circ} \mathrm{C}$. On each body part, measurements were repeated at three different points using a $\mathrm{pH}$ meter (Model PC 510, Cyber scan, Singapore). Similarly to $\mathrm{pH}$, meat color $\left(\mathrm{L}^{*} \mathrm{a}^{*} \mathrm{~b}^{*}\right)$ was measured on left breast and legs, but measurements were repeated two different points of each part (Fanatico et al. 2007; Sarica et al. 2011) using a colorimeter (Konica Minolta CR-400 colorimeter). Mean values for both color and $\mathrm{pH}$ values were calculated and recorded.

Drip loss was evaluated by suspending 1 intact fillet in a sealed glass box for $48 \mathrm{~h}$ at $2-4{ }^{\circ} \mathrm{C}$ and expressed as percentage of weight loss during storage (Bianchi et al. 2007). Whole samples of both breast and leg muscles (20 g) were placed in uncovered aluminum pans and roasted in an electric oven pre-heated to $200{ }^{\circ} \mathrm{C}$ for 15 min until meat samples reached an internal temperature of $80{ }^{\circ} \mathrm{C}$. Samples were cooled for $30 \mathrm{~min}$ to about $15^{\circ} \mathrm{C}$ and dried on the surface with paper towels, and cooking loss was estimated as the percentage of the weight of the roasted samples with respect to the raw ones (Castellini et al. 2002). Meat water-holding capacity (WHC) was determined by calculating the weight-loss of a 1-g sample after centrifuging it for $4 \mathrm{~min}$ at $1500 \mathrm{xg}$ and drying it overnight at $70{ }^{\circ} \mathrm{C}$ (Castellini et al. 2002). Total digestive tract was weighed with an electronic bascule in precision of $0.01 \mathrm{~g}$. Spleen, pancreas and craw was carefully separated from digestive tract and individually weighed with same bascule. an electronic bascule with precision of $0.01 \mathrm{~g}$. Digestive tract was laid on a flat surface and total length was measured with a ruler with accuracy of $1 \mathrm{~mm}$. Intestines were also measured with same method. The data about digestive tract organs was expressed as the percentage to body weight.

\subsection{Statistical analysis}

SPSS Software was used in the analysis. Analysis of variance with a factorial arrangement was used to test the effects of production system, age, sex and the interactions among these factors. Data was subjected to arc-sine transformation, and genotype and slaughter-age means were separated using Duncan's multiple range test. A level of $\mathrm{P}<0.05$ was considered statistically significant.

\section{Results and Discussion}

Color and $\mathrm{pH}$ values measured at different slaughter ages were given in Table 1. Lightness ( $\left.\mathrm{L}^{*}\right)$ values of breast meat were ranged between 50.18 and 57.95 while these values were between 46.69 and 54.32 for thigh meat. Production system only affected the thigh-meat yellowness and birds reared in outdoor had higher $\mathrm{b}^{*}$ values $(1.33$ vs 0.53 ; $\mathrm{P}<0.01)$, whereas gender only affected thigh-meat redness and females had higher $\mathrm{a}^{*}$ values $(8.65$ vs $7.74 ; \mathrm{P}<0.05)$. All meat color traits were affected by slaughter age $(\mathrm{P}<0.01 ; \mathrm{P}<0.05)$. Neither production system nor gender affected meat $\mathrm{pH}$. Slaughter age had a significant effect on thigh meat $\mathrm{pH}(\mathrm{P}<0.01)$.

$\mathrm{L}^{*}$ value ranges from 0 to 100 which gives the lightness from black to white (Papadakis et al. 2000). Mean $\mathrm{L}^{*}$ values of breast meat obtained in our study were found parallel with the findings of Hofbauer et al. (2010) and Kokoszynski et al. (2012) who found $\mathrm{L}$ values of breast meat between 51.4 and 54.2. There are also studies found the breast meat lightness lower. Fernye et al. (2017) and Dvoŕák et al. (2007) reported the breast meat lightness of pheasant breast meat to 49.27 and 41.19 , respectively. Different factors could have effect on this variation. Breed, age, sex, diet, breeding practices, $\mathrm{pH}$, total haem and 
mygoblobin content are considered as factors affect meat colour. It is expected older birds to have higher myoglobin content (Wideman et al. 2016). This has to result with lower $\mathrm{L}^{*}$ values at older slaughter ages. Contrarily, L* values of breast and thigh meat were decreased at 16 weeks of age and then increased to 14 week's level at 18 weeks. This could be related to slaughter and post mortem processing. Evolution time postmortem (Culioli et al. 1990), the residual blood amount is among the key factors which affect poultry meat color quality (Mohamed \& Mohamed 2012). Also, it is reported that breast muscle has significantly lower myoglobin content than the thigh muscle. The number of red muscle fibres are higher in thigh muscle, while the breast meat is mostly composed of white fibres (Barbut 2001). Red fibres have high mygoglobin content than white fibres (Wideman et al. 2016). The numerical values of $a^{*}$ and $b^{*}$ range from -120 to +120 with a* ranging from green if negative to red if positive. Similarly, $b^{*}$ ranging from blue if negative to yellow if positive (Papadakis et al. 2000). According to this, it is normal to thigh meat had higher $\mathrm{a}^{*}$ values than breast meat. Breast and thigh meat redness determined in this study found similar to the findings of Kokoszynski et al. (2012) who found a* value 3.8 for breast meat and Kotowicz et al. (2012) who found it 10.5 for thigh meat. Also, thigh meat had lower L* values than breast meat in our study. This could be related to $\mathrm{pH}$ levels of both breast and thigh meat. Fletcher (1999), reported that $\mathrm{pH}$ of meat has a strong effect on meat color with higher $\mathrm{pH}$ values resulting in a darker meat. $\mathrm{pH}$ levels of both breast and thigh meat were found higher than reported values for pheasant meat. Kotowicz et al. (2012) reported pH of breast and thigh meat 5.57 and 5.95 respectively, while, Kokoszynski et al. (2012) found $\mathrm{pH}$ of breast and thigh meat as 5.74 and 6.57. It is thought that this is due to glycogen concentration in the muscles which could be related to struggling during slaughter (Debut et al. 2003). Yellowness ( $\mathrm{b}^{*}$ ) of breast and thigh meat was found lower than the reported values of previous studies. Kotowicz et al. (2012) determined the breast meat $b^{*}$ value between 12.7 and 15.3; and thigh meat yellowness between 6.34 and 9.98. Fernye et al. (2017) and Kokoszynski et al. (2012) found the yellowness of pheasant breast meat between 4.8 and 7.59. This could also be related to pH. Allen et al. (1998) showed that lightness $\left(\mathrm{L}^{*}\right)$ and yellowness $\left(\mathrm{b}^{*}\right)$ were found to correlate negatively to $\mathrm{pH}$, whereas redness (a*) had a positive correlation.

Table 1- Color and pH values of pheasant meat at different ages

\begin{tabular}{|c|c|c|c|c|c|c|c|c|c|c|}
\hline \multirow{2}{*}{$\begin{array}{l}\text { Production } \\
\text { System }\end{array}$} & \multirow{2}{*}{$\begin{array}{c}\text { Slaughter } \\
\text { Age(weeks) }\end{array}$} & \multirow{2}{*}{ Gender } & \multicolumn{3}{|c|}{ Breast color } & \multicolumn{3}{|c|}{ Thigh color } & \multirow{2}{*}{$\begin{array}{c}\text { Breast } \\
\text { pH }\end{array}$} & \multirow{2}{*}{$\begin{array}{c}\text { Thigh } \\
\text { pH }\end{array}$} \\
\hline & & & $L$ & $a$ & $b$ & $L$ & $a$ & $b$ & & \\
\hline \multirow{6}{*}{ Free-range } & \multirow{2}{*}{14} & $M$ & 56.18 & 2.90 & 2.88 & 53.90 & 7.85 & 1.33 & 6.75 & 7.22 \\
\hline & & $\mathrm{F}$ & 55.12 & 2.84 & 2.88 & 49.07 & 7.31 & 1.09 & 6.82 & 7.23 \\
\hline & \multirow{2}{*}{16} & $\mathrm{M}$ & 51.01 & 3.04 & 1.23 & 50.75 & 8.56 & 0.44 & 6.80 & 6.97 \\
\hline & & $\mathrm{F}$ & 50.97 & 3.29 & 3.01 & 46.69 & 9.51 & 0.21 & 6.75 & 6.93 \\
\hline & \multirow{2}{*}{18} & $\mathrm{M}$ & 55.87 & 2.35 & 2.80 & 52.60 & 9.37 & 1.42 & 6.65 & 6.91 \\
\hline & & $\mathrm{F}$ & 54.22 & 4.73 & 4.82 & 51.95 & 9.51 & 3.47 & 6.56 & 6.97 \\
\hline \multirow{7}{*}{ Indoor } & \multirow{2}{*}{14} & $\mathrm{M}$ & 54.71 & 2.81 & 2.37 & 54.32 & 8.40 & 1.32 & 6.84 & 7.21 \\
\hline & & $\mathrm{F}$ & 56.09 & 2.23 & 2.67 & 54.22 & 7.48 & 0.77 & 6.67 & 7.21 \\
\hline & \multirow{2}{*}{16} & $\mathrm{M}$ & 50.18 & 3.25 & 0.66 & 49.70 & 7.47 & 1.57 & 6.79 & 7.02 \\
\hline & & $\mathrm{F}$ & 51.71 & 3.23 & 1.36 & 48.41 & 7.35 & 0.72 & 6.68 & 7.03 \\
\hline & \multirow{3}{*}{18} & $\mathrm{M}$ & 57.95 & 4.43 & 4.75 & 51.76 & 10.27 & 1.85 & 6.71 & 6.91 \\
\hline & & $\mathrm{F}$ & 53.82 & 3.26 & 3.12 & 50.53 & 8.56 & 1.52 & 6.77 & 7.16 \\
\hline & & SEM & 0.615 & 0.154 & 0.270 & 0.518 & 0.123 & 0.172 & 0.021 & 0.020 \\
\hline \multicolumn{11}{|c|}{ Effects } \\
\hline \multirow{2}{*}{\multicolumn{2}{|c|}{ Production system }} & FR & 53.89 & 3.19 & 2.93 & 51.32 & 8.13 & 1.33 & 6.72 & 7.04 \\
\hline & & IN & 54.07 & 3.20 & 2.49 & 51.49 & 8.25 & 0.53 & 6.75 & 7.09 \\
\hline \multirow{3}{*}{\multicolumn{2}{|c|}{ Slaughter age }} & 14 & $55.52 \mathrm{a}$ & $2.69 \mathrm{~b}$ & $2.69 \mathrm{~b}$ & $52.88 \mathrm{a}$ & $7.76 b$ & $1.13 \mathrm{~b}$ & 6.77 & $7.22 \mathrm{a}$ \\
\hline & & 16 & $50.96 \mathrm{~b}$ & $3.20 \mathrm{ab}$ & $1.56 \mathrm{c}$ & $49.63 b$ & $7.40 \mathrm{~b}$ & $0.41 \mathrm{c}$ & 6.76 & $6.99 \mathrm{~b}$ \\
\hline & & 18 & $55.46 \mathrm{a}$ & $3.69 \mathrm{a}$ & $3.87 \mathrm{a}$ & $51.71 \mathrm{ab}$ & $9.43 \mathrm{a}$ & $2.07 \mathrm{a}$ & 6.68 & $6.99 \mathrm{~b}$ \\
\hline \multirow{2}{*}{\multicolumn{2}{|c|}{ Gender }} & $\mathrm{M}$ & 54.32 & 3.13 & 2.97 & 52.17 & 8.65 & 0.80 & 6.76 & 7.04 \\
\hline & & $\mathrm{F}$ & 53.65 & 3.26 & 2.44 & 50.64 & 7.74 & 1.06 & 6.71 & 7.09 \\
\hline \multirow{3}{*}{\multicolumn{2}{|c|}{$\begin{array}{l}\text { Production syst } \\
\text { Slaughter age } \\
\text { Gender }\end{array}$}} & & NS & NS & NS & NS & NS & $*$ & NS & NS \\
\hline & & & $* *$ & $*$ & $* *$ & $*$ & $* *$ & $* *$ & NS & $* *$ \\
\hline & & & NS & NS & NS & NS & $* *$ & NS & NS & NS \\
\hline
\end{tabular}

G; Gender, *; P<0.05, **; P<0.01, SEM; Standard Error of Means, NS; Insignificant, FR; Free-range, IN; Indoor, M; Male, F; Female, a, b, c; Means within columns with no common superscript letter differ significantly

Water holding capacity (WHC), Drip Loss (DL) and Cooking Loss (CL) of pheasant meat at different ages were given in Table 2. Breast meat WHC was ranged between $72.61 \%$ and $74.41 \%$ and was not affected by production system, slaughter and gender. Thigh meat WHC values were found higher than breast WHC and only significantly affected by slaughter age $(\mathrm{P}<0.01)$ and decreased by maturation. Production system and gender did not significantly affect DL or CL of breast and thigh meat. These traits were significantly affected by slaughter age. Drip loss increased at 16 weeks of age and then decreased at 18 weeks of age. But cooking loss increased at older ages. The water binding properties of meat was evaluated by measuring drip loss, WHC and cook loss (Allen et al. 1998). The WHC of meat is an important trait in terms of eating quality and has an influence on product yield (Cheng \& Sun, 2008). Breast meat WHC was found around 73\% and was not affected by production system, slaughter and gender in our study. Our finding was in parallel with the result of Kokoszynski et al. (2014) who found the breast meat WHC of pheasants $72 \%$ at 17 weeks of age. Contrary to our finding they found that WHC increased 
by delayed slaughter age. Thigh meat had higher WHC than breast meat and found around 75\%. Kokoszynski et al. (2012) reported that protein hydration, which is higher in leg muscles, causes increased water binding Also, the WHC was decreased at older slaughter ages. Kokoszynski et al. (2014) reported same decreasing tendency for leg muscle WHC of pheasants at different slaughter ages.

Table 2- Water holding capacity, drip loss and cooking loss of pheasant meat at different ages

\begin{tabular}{|c|c|c|c|c|c|c|c|c|}
\hline \multirow{2}{*}{$\begin{array}{l}\text { Production } \\
\text { System }\end{array}$} & \multirow{2}{*}{$\begin{array}{l}\text { Slaughter } \\
\text { Age }\end{array}$} & \multirow[t]{2}{*}{ Gender } & \multicolumn{2}{|c|}{ WHC (\%) } & \multicolumn{2}{|c|}{ Drip Loss (\%) } & \multicolumn{2}{|c|}{ Cooking Loss (\%) } \\
\hline & & & Breast & Thigh & Breast & Thigh & Breast & Thigh \\
\hline \multirow{6}{*}{ Free-range } & \multirow{2}{*}{14} & $\mathrm{M}$ & 73.19 & 77.12 & 3.88 & 3.30 & 10.89 & 13.10 \\
\hline & & $\mathrm{F}$ & 74.38 & 76.22 & 4.18 & 3.50 & 10.28 & 11.87 \\
\hline & \multirow{2}{*}{16} & M & 73.67 & 75.47 & 4.62 & 3.90 & 10.43 & 13.85 \\
\hline & & $\mathrm{F}$ & 73.54 & 75.14 & 4.82 & 4.25 & 12.37 & 14.40 \\
\hline & \multirow{2}{*}{18} & M & 74.03 & 73.98 & 3.55 & 2.49 & 13.89 & 17.16 \\
\hline & & $\mathrm{F}$ & 72.61 & 74.51 & 3.36 & 1.95 & 17.62 & 17.00 \\
\hline \multirow{8}{*}{ Indoor } & \multirow{2}{*}{14} & $\mathrm{M}$ & 73.58 & 78.19 & 2.72 & 3.74 & 10.34 & 12.64 \\
\hline & & $\mathrm{F}$ & 74.41 & 75.67 & 4.19 & 3.17 & 12.58 & 13.77 \\
\hline & \multirow{2}{*}{16} & M & 73.77 & 76.53 & 4.67 & 4.53 & 11.64 & 12.47 \\
\hline & & $\mathrm{F}$ & 73.44 & 76.91 & 4.67 & 3.85 & 10.81 & 12.18 \\
\hline & \multirow{2}{*}{18} & M & 73.44 & 75.28 & 3.19 & 1.88 & 14.14 & 16.73 \\
\hline & & $\mathrm{F}$ & 74.08 & 72.28 & 2.88 & 1.60 & 12.18 & 14.21 \\
\hline & \multicolumn{2}{|c|}{ SEM } & 0.147 & 0.281 & 0.121 & 0.119 & 0.356 & 0.259 \\
\hline & \multicolumn{8}{|c|}{ Effects } \\
\hline \multirow[t]{2}{*}{ Production system } & & $\overline{F R}$ & 73.57 & 75.41 & 4.07 & 3.23 & 12.58 & 14.56 \\
\hline & & IN & 73.79 & 75.89 & 3.72 & 3.13 & 11.95 & 13.67 \\
\hline \multirow{3}{*}{ Slaughter age } & & 14 & 73.89 & $76.80 \mathrm{a}$ & $3.74 a$ & $3.43 b$ & $11.02 \mathrm{~b}$ & $12.84 b$ \\
\hline & & 16 & 73.60 & $76.01 \mathrm{a}$ & $4.69 a$ & $4.13 \mathrm{a}$ & $11.31 \mathrm{~b}$ & $13.22 \mathrm{~b}$ \\
\hline & & 18 & 73.54 & $74.17 \mathrm{~b}$ & $3.25 \mathrm{~b}$ & $1.98 \mathrm{c}$ & $14.46 \mathrm{a}$ & $16.28 \mathrm{a}$ \\
\hline \multirow[t]{2}{*}{ Gender } & & $\mathrm{M}$ & 73.61 & 76.10 & 3.77 & 3.31 & 11.89 & 14.32 \\
\hline & & $\mathrm{F}$ & 73.74 & 75.21 & 4.02 & 3.05 & 12.64 & 13.91 \\
\hline Production system & & & NS & NS & NS & NS & NS & NS \\
\hline Slaughter age & & & NS & $* *$ & $* *$ & $* *$ & $* *$ & $* *$ \\
\hline Gender & & & NS & NS & NS & NS & NS & NS \\
\hline
\end{tabular}

WHC; Water holding capacity, FR; Free-range, IN; Indoor, NS; Insignificant, M; Male, F; Female, **; P<0.01, SEM; Standard Error of Means, a, b, c; Means within columns with no common superscript letter differ significantly $(\mathrm{P}<0.05)$

Water loss is s problem during processing of meat. It is frequently expressed as drip loss, expressible water, cook loss, and cooling loss depending upon the stage during processing in which it was measured Cheng \& Sun (2008). Poor WHC caused more drip loss (Warriss 2000). In line with this, drip loss of breast meat was found higher than thigh meat, because breast meat had lower WHC. Cooking loss was significantly increased by slaughter age both for breast and thigh meat. Cooking of meat denatures different meat proteins and this denaturation causes changes which results in cooking loss (Honikel 1998). High WHC results in less water loss during cooking and good juiciness when chewing (Tlhong 2008).

Immune system of birds develops after hatch by develop of digestive tract. Development of digestive system in poultry species could be at different rates due to many factors (Lilja 1983). The species of the bird, gender, age and physiological status of the birds are the most important factors on this rate (Wasilewski et al. 2015). Feed has also an effect on development of digestive tract (Gille et al. 1999). Production system did not significantly affect total digestive tract weight ratio to body weight and length in our study (Table 3). This could be related to feed formula because birds fed with same feed formula in both systems. Similarly, the rate of digestive tract weight to body weight did not differ between males and females. But males had longer digestive tract than females (Table $3, \mathrm{P}<0.01$ ). Digestive tract length significantly increased at older ages, but the rate of weight to body weight was significantly decreased $(\mathrm{P}<0.01)$. These were expected results related to body weight. Digestive organs grow more rapidly than body weight at younger ages (Sell et al. 1991). Therefore the rate of digestive tract decreases at older ages. Rates of other digestive organs (spleen, pancreas and craw) to body weight were similarly affected by only slaughter age. They were affected by neither production system nor gender. Findings of Yovchev et al. (2012) were in parallel with our results. Small and large intestine lengths of birds reared in free-range system were significantly longer than indoor. Bartlett et al. (2015) reported that birds reared in free-range system or on pasture had access to consume forage, insects etc., and this could cause intestines to develop better. The differences of intestine lengths between both sexes were not found significant. Both small and large intestine lengths significantly decreased at older ages. These results were parallel with the findings of Yovchev et al. (2012) who found small intestine lengths $11.6 \mathrm{~cm}, 11.2 \mathrm{~cm}$ and $10.5 \mathrm{~cm}$ at 15,17 and 19 weeks of ages, respectively. 
Table 3- Effect of production system and slaughter age on some digestive tract traits of pheasants at different ages

\begin{tabular}{|c|c|c|c|c|c|c|c|c|c|c|c|}
\hline $\begin{array}{l}\text { Production } \\
\text { System }\end{array}$ & $S A$ & $G$ & $\begin{array}{l}B W \\
(g)\end{array}$ & $\begin{array}{c}\text { TDT } \\
\text { Weight } \\
/ B W(\%)\end{array}$ & $\begin{array}{c}\text { TGT } \\
\text { Length } \\
(\mathrm{cm})\end{array}$ & $\begin{array}{c}\text { Spleen } \\
\text { /BW } \\
(\%)\end{array}$ & $\begin{array}{c}\text { Pancreas } \\
/ B W \\
(\%)\end{array}$ & $\begin{array}{l}S I L \\
(\mathrm{~cm})\end{array}$ & $\begin{array}{r}L I L \\
(\mathrm{~cm})\end{array}$ & $\begin{array}{r}C L \\
(\mathrm{~cm})\end{array}$ & $\begin{array}{c}\text { Craw } \\
\text { weight } \\
/ B W(\%)\end{array}$ \\
\hline \multirow{6}{*}{ Free-Range } & \multirow{2}{*}{14} & $\mathrm{M}$ & 1008.3 & 2.67 & 124.88 & 0.06 & 0.19 & 96.92 & 9.32 & 13.75 & 0.27 \\
\hline & & $\mathrm{F}$ & 806.9 & 2.43 & 118.63 & 0.06 & 0.21 & 94.80 & 9.27 & 12.55 & 0.25 \\
\hline & \multirow{2}{*}{16} & M & 1160.8 & 2.35 & 141.70 & 0.06 & 0.18 & 103.35 & 9.87 & 16.50 & 0.31 \\
\hline & & $\mathrm{F}$ & 873.4 & 2.27 & 127.70 & 0.08 & 0.17 & 102.60 & 9.35 & 15.52 & 0.33 \\
\hline & \multirow{2}{*}{18} & M & 1258.1 & 2.39 & 147.33 & 0.05 & 0.15 & 94.20 & 8.75 & 13.72 & 0.23 \\
\hline & & $\mathrm{F}$ & 953.5 & 2.21 & 123.25 & 0.05 & 0.17 & 92 & 9.02 & 12.87 & 0.34 \\
\hline \multirow{7}{*}{ Indoor } & \multirow{2}{*}{14} & $\mathrm{M}$ & 967.1 & 2.40 & 123.30 & 0.05 & 0.19 & 116.07 & 10.12 & 13.52 & 0.24 \\
\hline & & $\mathrm{F}$ & 785.8 & 2.49 & 120.85 & 0.05 & 0.18 & 122.60 & 9.82 & 13.60 & 0.28 \\
\hline & \multirow{2}{*}{16} & M & 1110.5 & 2.30 & 135.93 & 0.07 & 0.15 & 98.27 & 10.60 & 16.45 & 0.24 \\
\hline & & $\mathrm{F}$ & 867.1 & 2.46 & 127.68 & 0.06 & 0.16 & 99.80 & 10.10 & 16.42 & 0.33 \\
\hline & \multirow{2}{*}{18} & M & 1205.6 & 1.93 & 135.93 & 0.06 & 0.13 & 99.70 & 9.90 & 15.40 & 0.33 \\
\hline & & $\mathrm{F}$ & 962.9 & 2.01 & 120.88 & 0.05 & 0.15 & 88.70 & 8.70 & 12.77 & 0.29 \\
\hline & \multicolumn{2}{|c|}{ SEM } & 8.803 & 0.031 & 1.124 & 0.02 & 0.005 & 1.315 & 0.143 & 0.272 & 0.009 \\
\hline \multicolumn{12}{|c|}{ Effects } \\
\hline \multirow{3}{*}{$\begin{array}{l}\text { Production } \\
\text { System }\end{array}$} & & & $\mathrm{NS}$ & NS & $\mathrm{NS}$ & $\mathrm{NS}$ & $\mathrm{NS}$ & $*$ & $*$ & $\mathrm{NS}$ & $\mathrm{NS}$ \\
\hline & & & 1010.0 & 2.39 & 130.57 & 0.06 & 0.19 & 97.31 & 9.27 & 14.15 & 0.28 \\
\hline & Inc & & 983.2 & 2.27 & 127.43 & 0.06 & 0.17 & 102.52 & 9.87 & 14.70 & 0.28 \\
\hline \multirow[t]{4}{*}{ Slaughter Age } & & & $* *$ & $* *$ & $* *$ & $*$ & $* *$ & $*$ & $*$ & $* *$ & $*$ \\
\hline & & & $892 c$ & $2.50 \mathrm{a}$ & $121.91 b$ & $0.06 \mathrm{ab}$ & $0.19 \mathrm{a}$ & $105.10 \mathrm{a}$ & $9.64 a b$ & $13.36 \mathrm{~b}$ & $0.25 b$ \\
\hline & & & $1003 b$ & $2.35 \mathrm{a}$ & $133.25 \mathrm{a}$ & $0.07 \mathrm{a}$ & $0.16 \mathrm{~b}$ & $101.01 \mathrm{a}$ & $9.98 \mathrm{a}$ & $16.22 \mathrm{a}$ & $0.30 \mathrm{a}$ \\
\hline & & & $1095 \mathrm{a}$ & $2.14 \mathrm{~b}$ & $131.84 \mathrm{a}$ & $0.05 \mathrm{ab}$ & $0.15 \mathrm{~b}$ & $93.65 \mathrm{~b}$ & $9.09 \mathrm{~b}$ & $13.69 \mathrm{~b}$ & $0.29 \mathrm{ab}$ \\
\hline \multirow[t]{3}{*}{ Gender } & & & $* *$ & NS & $* *$ & NS & NS & NS & NS & NS & NS \\
\hline & & & 1118.3 & 2.34 & 134.84 & 0.06 & 0.16 & 101.42 & 9.76 & 14.89 & 0.27 \\
\hline & & & 874.9 & 2.31 & 123.16 & 0.06 & 0.17 & 98.42 & 9.38 & 13.96 & 0.30 \\
\hline
\end{tabular}

*; P<0.05, **; P<0.01, BW; Body weight, TDT; Total digestive tract, SIL; Small intestine length, LIL; Large intestine length, CL; Cecum length, SEM;

Standard Error of Means, NS; Insignificant, M; Male, F;Female, a, b, c; Means within columns with no common superscript letter differ significantly

Pheasants are game birds and preferred for niche markets. Rearing them in indoor systems became popular to meet the demand. On the other hand, the reason of consumers' preference is their gamey taste. Also, they are still not fully domesticated birds. Therefore, free-range systems could be more suitable for pheasant rearing in overall terms. This could be related to increased welfare conditions in free-range area for these non-domesticated birds. In conclusion, non-domesticated birds like pheasants have to be reared in animal friendly or organic production systems. This production model could have advantages both for consumers and producers.

\section{Acknowledgements}

Authors are thankful to Abalioglu Feed mill Co. for their support.

\section{References}

Adamski M, Kuzniacka J \& Milczewska N (2017). Preferences of consumers for choosing poultry meat. Polish Journal of Naturel Science 32: $261-271$

Allen C D, Fletcher D L, Northcutt J K \& Russell S M (1998). The relationship of broiler breast color to meat quality and shelf-life. Poultry Science 77: 361-366. https://doi.org/10.1093/ps/77.2.361

Barbut S (2001). Basic anatomy and muscle biology. Poultry Products Processing: An Industry Guide. CRC Press pp. 31-60

Bartlett J, Liles K M \& Beckford R C (2015). Comparing the effects of conventional and pastured poultry production systems on broiler performance and meat quality. Journal of Agriculture and Life Sciences 2: 29-36

Bianchi M, Petracci M, Sirri F, Folegatti E, Franchini A \& Meluzzi A (2007). The influence of the season and market class of broiler chickens on breast meat quality traits. Poultry Science 86 : 959-963 https://doi.org/10.1093/ps/86.5.959

Bodnar K, Benak A \& Bodnarne Skobrak E (2010). Analyses of consumer preferences and attitudes on Hungarian game meat market (preliminary report). Seria Agronomie 53: 9-12

Castellini C, Mugnai C \& Dal Bosco A (2002). Effect of organic production system on broiler carcass and meat quality. Meat Science 60: 219-225 doi: 10.1016/s0309-1740(01)00124-3

Cheng Q \& Sun D W (2008). Factors affecting the water holding capacity of red meat products: a review of recent research advances. Critical reviews in food science and nutrition 48(2): 137-159. https://doi.org/10.1080/10408390601177647

Culioli J, Touraille C, Bordes P \& Girard J P (1990). Inventory of quality problems currently faced chicken fillets in French slaughterhouses. Archiv fur Geflugelkunde 53: 237-245 
Debut M, Berri C, Baeza E, Sellier N, Arnould C, Guemene D \& Le Bihan-Duval E (2003). Variation of chicken technological meat quality in relation to genotype and preslaughter stress conditions. Poultry Science 82(12): 1829-1838 doi: 10.1093/ps/82.12.1829

Dvořák P, Kunová J \& Vodňanský M (2007). Change of colour and pH-value in pheasant meat after exposure to ionizing radiation. Acta Veterinaria Brno 76(8): 67-71 https://doi.org/10.2754/avb200776S8S067

Fanatico A C, Pillai P B, Emmert J L \& Owens C M (2007). Meat quality of slow-and fast-growing chicken genotypes fed low-nutrient or standard diets and raised indoors or with outdoor access. Poultry Science 86(10): 2245-2255 doi: 10.1093/ps/86.10.2245

Faostat 2017: http://www.fao.org/faostat/en/\#data/EMN, Last access: December 2018

Fernye C, Erdélyi M, Ancsin Z, Bócsai A \& Mézes M (2017). Some chemical and physical characteristics of farmed pheasant hens (Phasianus cholchicus) breast meat. Columella: Journal of Agricultural and Environmental Sciences 4(1): 7-13 DOI: 10.18380/SZIE.COLUM.2017.4.1.7

Fletcher D (1999). Broiler breast meat colour variation, pH, and texture. Poultry Science 78: 1323-1327

Franco D \& Lorenzo J M (2013). Meat quality and nutritional composition of pheasants (Phasianus colchicus) reared in an extensive system. British Poultry Science 54(5): 594-602. https://doi.org/10.1080/00071668.2013.828195

Gille U, Salomon F V \& Rönnert J (1999). Growth of digestive organs in ducks with considerations on their growth in birds in general. British Poultry Science 40: 194-202. https://doi.org/10.1080/00071669987593

Golze M (2010). Fasanenproduktion zur fleischgewinnung und zum Auswildern. Rundschau für Fleischhygiene und Lebensmittelüberwachung 62: 9-12

Hofbauer P, Smulders F J M, Vodnansky M, Paulsen P \& El-Ghareeb W R A (2010). Note on meat quality traits of pheasant (Phasianus colchicus). European Journal of Wildlife Research 56: 809-813. DOI 10.1007/s10344-010-0396-7

Honikel K O (1998). Reference methods for the assessment of physical attributes of meat. Meat Science 49: 447-457 https://doi.org/10.1016/S0309-1740(98)00034-5

Kokoszynski D, Bernacki Z \& Duszynski L (2012). Body conformation, carcass composition and physicochemical and sensory properties of meat from pheasants of different origin. Czech Journal of Animal Science 57: 115-124. https://doi.org/10.17221/5564-CJAS

Kokoszynski D, Bernacki Z \& Pieczewski W (2014). Carcass composition and quality of meat from game pheasants (P. colchicus) depending on age and sex. European Poultry Science 78 Doi: 10.1399/eps.2014.16

Kotowicz M, Lachowicz K, Lisiecki S, Szczygielski M \& Zych A (2012). Characteristics of common pheasant (Phasianus colchicus) meat. Archiv fur Geflügelkunde 76: 270-276

Lilja C A (1983). Comparative study of postnatal growth and organ development in some species of birds Growth 47: $317-339$

Mohamed B \& Mohamed I (2012). The Effects of residual blood of carcasses on poultry technological quality. Food and Nutrition Sciences 3: 1382-1386. DOI:10.4236/fns.2012.310181

Papadakis S E, Abdul-Malek S, Kamdem R E \& Yam K L (2010). A versatile and inexpensive technique for measuring colour of foods. Food Technology 5: 48-51

Sarica M, Ocak N, Turhan S, Kop C \& Yamak U S (2011). Evaluation of meat quality from 3 turkey genotypes reared with or without outdoor access. Poultry Science 90: 1313-1323. https://doi.org/10.3382/ps.2009-00600

Sell J L, Angel C R, Piguer F J, Mallarino E G \& AlBatshan NA 1991. Development patterns of selected characteristics of the gastrointestinal tract of young turkeys. Poultry Science 70:1200-1215 doi: 10.3382/ps.0701200

Tlhong T M (2008). Meat quality of raw and processed guinea fowl (Numeda meleagris), Master thesis. Stellenbosch University, South Africa, $138 \mathrm{p}$

Warriss P D (2000). Meat Science, An introductory text. Bristol: UK Biddles Ltd., CABI

Wasilewski R, Kokoszynski D, Mieczkowska A, Bernacki Z \& Gorska A (2015). Structure of the digestive system of ducks depending on sex and genetic background, Acta Veterinaria Brno 84: 153-158. https://doi.org/10.2754/avb201584020153

Wideman N, O'Bryan C A \& Crandall P G (2016). Factors affecting poultry meat colour and consumer preferences- A review. World's Poultry Science Journal 72: 353-366 https://doi.org/10.1017/S0043933916000015

Yamak U S, Sarica M, Boz M A \& Ucar A (2018). Effect of production system (barn and free-range) and slaughter age on some production traits of guinea fowl. Poultry Science 97: 47-53 https://doi.org/10.3382/ps/pex265

Yovchev D, Dimitrov R, Kostov D \& Vladova D (2012). Age morphometry of some internal organs in common pheasant (phaslanus colchicus colchicus). Trakia Journal of Sciences 10: 48-52 